Коцко Т.А.

канд. економ. наук, доцент

Наиіональний технічний університет Украйни «КПI»

\title{
ФОРМУВАННЯ ОПЕРАЦІЙНОЇ СТРАТЕГІЇ ЕНЕРГОГЕНЕРУЮЧИХ ПІДПРИЄМСТВ УКРАЇНИ В УМОВАХ АКТИВІЗАЦЇ̈ ЗАГРОЗ ЗОВНІШНЬОГО СЕРЕДОВИЩА
}

\section{ФОРМИРОВАНИЯ ОПЕРАЦИОННОЙ СТРАТЕГИИ ЭНЕРГОГЕНЕРИРУЮЩИХ ПРЕДПРИЯТИЙ УКРАИНЫ В УСЛОВИЯХ АКТИВИЗАЦИИ УГРОЗ ВНЕШНЕЙ СРЕДЫ}

\section{OPERATING STRATEGY FORMATION IN UKRAINE'S ENERGY GENERATING COMPANIES UNDER THE CONDITIONS OF THREATS ACTIVATION OF THE EXTERNAL ENVIRONMENT}

\begin{abstract}
Розглядаються проблеми та можливості забезпечення ефективності розвитку енергогенеруючих підприємств України в умовах військово-політичної та макроекономічної нестабільності. Акиентується увага на тому, щзо врезультаті погіршення зовнішнього середовища хронічні проблеми низької рентабельності, дефіциту обігових та інвестииійних ресурсів доповнилися проблемами надійності
\end{abstract} паливозабезпечення вугільних ТЕС, суттєвими змінами попиту на паливно-енергетичні ресурси, швидким та критичним збільшенням вартості палива і енергії, а також різкими коливаннями навантаження в енергетичній системі краӥни. Доведено, щчо зазначені тендениії обумовлюють формування стійких передумов зростання виробничих витрат суб’єктів генерачї, обмежуючи передумови забезпечення їх стратегічної стійкості. Обтрунтовано необхідність перегляду політики розвитку енергогенеруючих підприємств, пошуку можливостей оптимізації їх ресурсного потенціалу через чітке визначення операційних пріоритетів, формування і реалізацію відповідної операційної стратегії.

Ключові слова: енергогенеруюче підприємство, паливно-енергетичні ресурси, нестабільність зовнішнього середовища, економічна безпека, операційна стратегія підприємства, стратегія мінімізації витрат

Рассматриваются проблемь и возможности обеспечения эффективности развития энергогенерирующих предприятий Украины в условиях военно-политической $u$ макроэкономической нестабильности. Акцентируется внимание на том, что в результате ухудшения внешней среды, хронические проблемы низкой рентабельности, дефицита оборотных и инвестиционных ресурсов дополнились проблемами надежности топливообеспечения угольных ТЭС, существенного изменения спроса на топливноэнергетические ресурсы, быстрого и критического увеличения стоимости топлива $и$ энергии, а также резкого колебания нагрузки в энергетической системе страны. Доказано, что указанные тенденции обусловливают формирование устойчивых предпосылок роста производственных затрат субъектов генерачии, ограничивая предпосылки обеспечения их стратегической устойчивости. Обоснована необходимость пересмотра политики развития энергогенерирующих предприятий, поиска возможностей оптимизации их 
ресурсного потенциала через четкое определение операционных приоритетов, формирование и реализацию соответствующей операционной стратегии.

Ключевые слова: энергогенерирующее предприятие, топливно-энергетические ресурсы, нестабильность внешней среды, экономическая безопасность, операционная стратегия предприятия, стратегия минимизации затрат.

The problems and opportunities to ensure the efficiency of power generation enterprises in Ukraine in terms of military, political and macroeconomic instability. The attention that the result of the deterioration of the environment chronic problems of low profitability, lack of working capital and investment resources supplemented problems of reliability of fuel supply coal thermal power plants, significant changes in demand for fuel and energy resources, rapid and critical increase in the cost of fuel and energy, and sharp fluctuations in the energy system of the country. It is proved that these trends lead to the formation of stable preconditions increase the production costs of generation, limiting premise of ensuring strategic stability. The necessity of revision of the development policy of power generating companies, seeking opportunities to optimize their resource potential through a clear definition of operational priorities, the formation and implementation of the operating strategy.

Key words: energy generation company, fuel and energy resources, instability of the environment, economic security, the operating strategy of the company, cost minimization strategy

Вступ. Паливно-енергетичний комплекс (ПЕК) України являє собою потужний та складний технологічний комплекс, об'єднуючи цілий ряд галузей промисловості, які забезпечують економіку паливно-енергетичними ресурсами (ПЕР). Від ефективності його функціонування залежить не лише ефективність суміжних галузей промисловості, але й національної економіки в цілому, і що значно важливіше, - можливості їі динамічної трансформації та адаптації до ринкових умов. Як показав досвід, саме зволікання з реформами у даній сфері, виявилося причиною системної ескалації загроз економічній безпеці держави у першу чергу за енергетичною складовою.

Формування ПЕК України відбувалося в межах моделі планової економіки, зорієнтованої перш за все на екстенсивні чинники розвитку, в основі якої була система неринкового ціноутворення. Відтак, з переходом до моделі конкурентної економіки, паливні та енергетичні підприємства опинилися в зовсім інших умовах, адаптація до яких, виявилася надзвичайно складною [1,4]. Значна взаємозалежність енергоекономічних чинників у прочесах відтворення, за відсутності реальних та послідових реформ, виявилася основою виникнення та системної ескалачї дестабілізуючих факторів на різних рівнях територіально-виробничої та управлінської iєрархії. Більше того, саме взаємозалежність процесів розвитку економічної та енергетичної сфер обумовила зволікання 3 реформами, які все ж довелося продовжувати, однак в значно складніших умовах, - умовах військовополітичної та макроекономічної нестабільності. 
Проблеми дефіцииту інвестиційних ресурсів, обігових коштів, модернізачії основних виробничих фондів, які завжди були актуальними для енергетичних компаній доповнилися проблемами дефіниту паливних ресурсів, стрімкого зростання собівартості виробництва палива та енергії через розгортання девальвачійних процесів, а також посилення ризиків пов'язаних із зменшенням надійності систем енергетики врезультаті падіння обсягів виробництва енергії, маневрування виробничими потужностями генеруючих підприємств тощо [3,9]. Подібні обставити заставили уряд країни кардинально переглянути політику тарифоутворення, в пожежному порядку організувати імпорт значних обсягів енергетичного вугілля, прискорити заходи щодо удосконалення моделі оптового ринку електроенергії, що дозволило забезпечити виконання базових функцій ПЕК. Однак, такі непередбачувані та нестабільні умови, обумовили необхідність переосмислення управлінської політики на рівні енергетичних компаній, i зокрема стратегій ї розвитку.

Постановка завдання. Основними цілями статті є дослідження змін у зовнішньому середовищі підприємств ПЕК, які пов'язані 3 наслідками військово-політичної нестабільності у країні, частковою втратою власної ресурсної бази електроенергетичної галузі, а також негативними тенденціями в економічній сфері, - процесами девальвації національної грошової одиниці, обмеженнями в доступі до інвестиційних ресурсів, змінами в структурі попиту на ПЕР та обгрунтування вихідних положень щодо формування операційної стратегії паливних та енергетичних підприємств, яка б дозволяла обмежувати дестабілізуючий вплив зовнішніх факторів на їх діяльність.

Методологія дослідження. Методологічною основою статті є праці вітчизняних та зарубіжних науковців у сфері вивчення проблем трансформації ринків енергетичних ресурсів та політики управління розвитком підприємств ПЕК. В процесі проведення досліджень використовувались методи узагальнення та порівняння, метод аналізу статистичних показників.

Результати дослідження. Пошук та обгрунтування можливих рішень в частині обмеження впливу потенційних та реальних ризиків на діяльність підприємств ПЕК звичайно ж потребує вивчення основних тенденцій у його розвитку, а також особливостей взаємовпливу енергоекономічних чинників у визначенні траєкторії макроекономічної динаміки. Разом з тим, з огляду на структурно-технологічні та функціональні особливості ПЕК, немає жодних сумнівів, щзо найбільш важливою сферою для пошуку управлінських рімень спрямованих на формування нехай певною мірою нестійких, однак стратегічно важливих передумов ефективного функиіонування його суб'єктів, є саме операційна сфера. Відтак, важливої уваги потребує чіткий вибір операційних пріоритетів підприємствами ПЕК, що звичайно ж передбачає формування відповідної операційної стратегії. Обгрунтування ж 
механізмів реалізації операційних пріоритетів необхідно забезпечити на основі узгодження базових пріоритетів як державної, так і корпоративної політики, тим більше в умовах значної економічної нестабільності.

Обгрунтовуючи теоретичні та практичні засади стратегічного управління підприємствами ПЕК перш за все необхідно звернути увагу на вугільні енергогенеруючі підприємства, - TЕС та вуглевидобувні підприємства. Адже в 2014 p. в загальній структурі виробництва електроенергії, частка іï виробництва на ТЕС склала 37,5\%, ТЕЦ - 3,8\%, комунальних ТЕЦ і блок станціях - 4,3\%, що разом фактично дорівнює обсягу виробництва на AEC, - 48,4\% [3, с. 61]. При тому, саме вугільні ТEC зорієнтовані на використання власного енергетичного ресурсу, а отже $\epsilon$ важливою складовою в системі забезпечення енергетичної безпеки держави. Так, за даними Міністерства палива та енергетики України балансові запаси вугілля країни становлять близько 56 млрд. тонн, наявність яких дозволила українським ТЕС відмовитись від імпорту природного газу й мазуту як палива, - в паливно-енергетичному балансі ТЕС частка вугілля зросла 3 30$50 \% 1991$ року до 98\% 2014 року [3, с. 50].Власне вугілля забезпечує близько $46 \%$ у загальному виробництві в Україні первісної енергії, а частка електроенергії, виробленої з використанням вугільної продукції, становить близько однієї чверті [6].

У науковій літературі досить широко та комплексно розкрито питання вибору операційних пріоритетів підприємствами [5,7,11]. Відповідні акиенти y даній площині були зроблені наприкінці 70-x - початку 80-x років професорами Гарвардської бізнес-школи, які обтрунтували тезу про неможливість та недоиільність кониентрації зусиль на досягнення підприсмством високих показників операщійної діяльності за усіма напрямами, а значить необхідність розроблення чітко сфокусованої стратегіï [11, с. 35,120]. Для підприємств ПЕК, в силу технологічних особливостей ïx функціонування, міжгалузевих взаємозв'язків, коло операційних пріоритетів $є$ обмеженим, однак серед таких пріоритетів як низькі витрати, висока якість продукції, рівень гнучкості, надійність енергота паливозабезпечення, найбільш важливе значення має саме пріоритет низьких витрат. При цьому його значимість, зажди була актуально, як в період фактичної відсутності ринків ПЕР, так і сьогодні, коли вони поступово розвиваються. Виходячи 3 точки зору завдань розвитку потенціалу підприємств у перспективі, за умови стабілізації макроекономічної ситуації, роль витратної складової в системі формування їх позитивних фінансових потоків лише зростатиме. Можливості для реалізаиії вказаного пріоритету передбачено існуючою моделлю оптового ринку електроенергії, відповідно до якої генеруючі компанії з найнижчою собівартістю отримують найбільше завантаження й найбільшу маржу [3,9]. Згідно із Законом України про «Про 
засади функціонування ринку електричної енергії України», який набув чинності $3 \quad 1$ січня 2014 p., 3 липня 2017 p. буде запроваджено повномасштабний конкурентний ринок електроенергії, який включатиме дві основні складові, - ринок двосторонніх контрактів і балансуючий ринок [3, с. 59], відтак конкуренція за низькі витрати зростатиме.

Як вітчизняними, так і іноземними науковцями розглядається багато підходів до трактування сутності операційної стратегії підприємства [7,8,11]. Так, Сумець О.М., Тумар М.Б., зазначають, що виробнича стратегія, як і будьяка інша стратегія (фінансова, маркетингова, кадрова), є комплексом дій, які реалізовуються на оперативному рівні та спрямовані виключно на досягнення стратегічних цілей підприємства, вона націлена на реалізацію виробничого процесу підприємства та максимізацію його ефективності [5, с. 94].

Омельяненко Т.В. під виробничою (операційною) стратегією розуміє функціональну стратегію підприємства, що являє собою комплекс взаємозв'язаних рішень щодо того, як $з$ технологічної, економічної, організаційної та ресурсної точок зору має бути організована нова чи змінена наявна виробнича діяльність підприємства 3 метою досягнення ним стратегічних конкурентних переваг [7, с. 282]. При цьому, науковець відзначає, що виробнича стратегія $є$ складовою загальної стратегії підприємства, вона має на меті набуття ним стратегічної конкурентної переваги і їй властивий підпорядкований характер, - розробляється на підтримку та для конкретизації загальнокорпоративної та бізнес-стратегії. Крім того, виробнича стратегія належить до категорії функціональних і має узгоджуватися 3 фінансовою, маркетинговою та всіма іншими функціональними стратегіями підприємства, вона конкретизується в наборі виробничо-стратегічних рішень, які охоплюють технологічний, ресурсний, організаційний та інші аспекти виробничої активності підприємства.

Беручи за основу тлумачення наведене у [11, с. 116], під операційною стратегію енергогенеруючого підприємства (компанії) слід розуміти підсистему корпоративної стратегії, щзо представлена у вигляді довгострокової програми конкретних дій зі створення та реалізаиії його продукиї і передбачає використання та розвиток виробничих потужностей $з$ метою досягнення стратегічної конкурентної переваги та забезпечення довготермінової прибутковості. Запропонований підхід може бути основою і для розкриття сутності операційної стратегії вуглевидобувного підприємства. Проте існуюча модель ринку вугілля ігнорує роль витрат у процесах купівліпродажу вугілля, а відтак і значення конкуренції між його суб'єктами.

Підходи до класифікації операційних стратегій підприємства також розкриті досить широко у літературі $[7,8,11]$. Найчастіше науковці виділяють такі виробничі стратегії: стратегія створення нового виробництва; стратегія використання існуючого виробничого потенціалу; стратегія організації 
виробництва; стратегія змін у технологічному процесі; стратегії впровадження оперативно-календарного планування та ін.

На думку Корецького М.X., Дєгтяра А.О., Дація О.I. найпоширенішими виробничими стратегіями є диверсифікація, спеціалізація, диференціація, концентрація, реконструкція, зниження собівартості [5, с. 95]. Як бачимо, науковці окремо виділяють стратегію зниження собівартості, яка звісно за своєю сутністю перетинається з стратегією мінімізації витрат.

Стєрлігова А.М. та Фель А.В. [8, с. 172] виділяють операційні стратегії виходячи 3 пріоритетів функціонування операційної системи бізнесу, стратегію мінімізації витрат; розвитку гнучкості операційної системи 3 розширення номенклатури, асортименту, зміни обсягу випуску; розвитку якості бізнес-процесів, продукції, послуг; стратегію мінімізації часу виконання замовлень. Перші дві групи стратегій, - (орієнтованих на мінімізацію витрат i розвиток гнучкості операційних систем) науковці відносять до традиційних, які використовуються з перших років розвитку класичного менеджменту. Інші групи стратегій, - розвиток якості та оптимізація часу є відносно новими, сучасними стратегіями.

У прочесі формування операиійної стратегії будь-якого підприємства до уваги слід брати иілу систему чинників [8, с. 149]. Першочергового аналізу потребує кон'юнктура ринку, тенденції його розвитку, поведінка конкурентів, регуляторна політика держави тощо. В останній час особливого значення набуває вагомість таких факторів як надійність поставок палива для генеруючих підприємств, його ціна та якість, зміни навантажень в об'єднаній енергетичній системі, а також курсові коливання, інфляційні процеси тощо. На рис. 1. систематизовано найбільш важливі чинники, які впливають на формування витрат енергогенеруючими підприємствами, - вугільними TEC, i які слід брати до уваги в процесі прийняття стратегічних рішень в операційній сфері енергогенеруючого підприємства (ТЕС).

\begin{tabular}{|c|c|c|c|}
\hline \multicolumn{2}{|c|}{$\begin{array}{c}\text { Стабільність паливозабезпечення } \\
\text { підприємства та робота виробничого } \\
\text { обладнання в сталому режимі }\end{array}$} & \multicolumn{2}{|c|}{$\begin{array}{c}\text { Якість (калорійність) палива та збалансо- } \\
\text { ваність структури енергетичного балансу } \\
\text { відповідно до технологічних вимог }\end{array}$} \\
\hline $\begin{array}{c}\text { Надійність матеріально- } \\
\text { технічного забезпечення } \\
\text { підприємства }\end{array}$ & $\begin{array}{r}\text { Чинники ф } \\
\text { енергс } \\
\text { під }\end{array}$ & $\begin{array}{l}\text { зання витрат } \\
\text { уючого } \\
\text { чства }\end{array}$ & $\begin{array}{c}\text { Рівень та механізм } \\
\text { інтегрованості в систему } \\
\text { міжгалузевих зв’язків }\end{array}$ \\
\hline \multicolumn{2}{|c|}{$\begin{array}{c}\text { Збалансованість енергетичного балансу } \\
\text { підприємства } 3 \text { точки зору витрат на } \\
\text { закупівлю палива }\end{array}$} & \multicolumn{2}{|c|}{$\begin{array}{c}\text { Оптимальний рівень використання } \\
\text { встановленої потужності, яка дозволяє } \\
\text { реалізувати ефект масштабу }\end{array}$} \\
\hline
\end{tabular}

Рис. 1. Чинники формування витрат енергогенеруючого підприємства (розроблено автором) 
Серед наведених чинників особливу увагу слід звернути на рівень та механізми інтегрованості підприємства в систему міжгалузевих зв'язків. Мова йде про те, що у сфері ПЕК можна досягати зменшення витрат через формування різного роду інтегрованих утворень, зокрема вертикальноінтегрованих енерговугільних компаній [1,3]. Інтеграція підприємств відкриває нові можливості для вирішення вищеописаних проблем, і що найважливіше, - для реалізації потенціалу синергетичного ефекту. 3 огляду на специфіку середовища діяльності сучасних підприємств, зазначений механізм можна розглядати і з точки зору формування антикризової політики. Досвід створення цілого ряду подібних утворень засвідчив свою доцільність, яскравим прикладом реалізації потенційних переваг формування подібних структур є компанія ДТЕК, якій навіть не зважаючи на втрату частини виробничих потужностей врезультаті військових дій на сході країни, вдалося ефективно вирішувати фінансові, виробничі проблеми, реалізувати інвестиційні програми та демонструвати позитивні результати діяльності.

Поряд 3 чинниками внутрішнього, організаційно-економічного та технологічного характеру великого значення набуває $i$ вплив зовнішніх, зокрема макроекономічних чинників. Так, доступ до недорогих позикових ресурсів є умовою надійності систем енергетики, вчасного виконання планових та позапланових ремонтних робіт, модернізації окремих технічних систем. Цінова стабільність, яка визначається і відсутністю валютних коливань дозволяє планувати та оптимізувати структуру енергетичних балансів підприємств 3 урахуванням критеріїв економічної ефективності, вимог технологічних режимів роботи обладнання.

Аналізуючи сучасні проблеми діяльності енергогенеруючих компаній, вугільних ТЕС, в першу чергу слід відзначити, критичний знос основних виробничих фондів, що в умовах дефіциту інвестиційних ресурсів $\epsilon$ обмежуючим фактором розвитку підприємств $(63,8 \%$ енергоблоків знаходяться за межею фізичного зносу [6]). Має місце висока енергоємність виробництва, - питомі витрати умовного палива для виробництва електроенергії на вітчизняних ТЕС і ТЕЦ сягають 379,4 кг у. п./тис. кВт./Г (у розвинутих країнах - 310-320 кг у. п./тис. кВт/г). Витрати на виробництво теплоенергії складають 179 кг у. п./Гкал (середньосвітовий показник 140-150 кг у. п.) [10, с. 76]. Відбулося суттєве посилення ризиків пов'язаних з паливо забезпеченням, - у зоні антитерористичної операції розміщено 85 шахт усіх форм власності, що становить 57\% від їхньої загальної кількості в Україні [3, c. 50]. Через дефіцит вугілля антрацитових марок та економічний спад ТЕС України протягом 2014 року зменшили виробництво на 12,6\%, до 68,5 млрд. кВт.год [3, с. 61]. Окремою проблемою залишається нестабільність режимів роботи обладнання, що формує передумови зростання витрат виробництва, прискорення зносу виробничих фондів. 
Важливість піднятих проблем, посилення їх актуальності підтверджують і результати дослідження енергетичного ринку України, яке було проведено у 2012 році компанією КПМГ у співпраці з IBCentre на основі опитування 34 галузевих експертів, а також фахівців вітчизняних і іноземних компаній, представлених в Україні у різноманітних підгалузях енергетики. Дослідження дозволили виявити основні чинники стримування розвитку енергетичної галузі України (рис. 2) [2, с. 5].

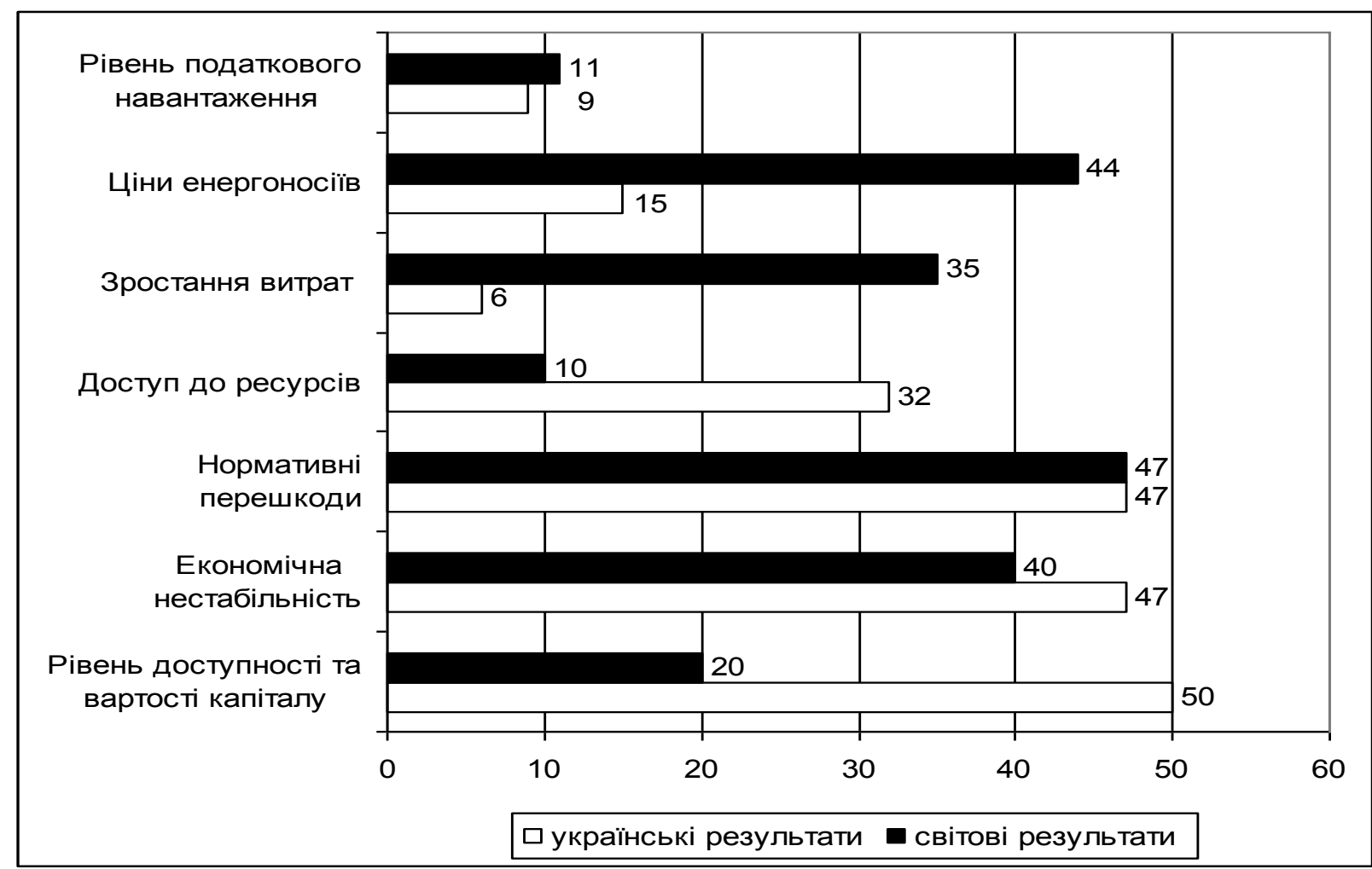

Рис. 2. Чинники, які стримують розвиток енергетичної галузі України, результати опитувань експертів (\% відповідей), 2012 p.

Джерело: [2, с. 5]

Як видно 3 рис. 2, найбільш важливими залишаються проблеми економічної нестабільності, доступу до інвестииійних ресурсів, а також нормативного регулювання, - близько 50\% відповідей респондентів. У значній мірі вони тісно взаємопов'язані і є свідченням несформованості повноцінних ринків палива та енергії, а також складної взаємозалежності процесів трансформації зазначених ринків з соціально-економічними трансформаціями в цілому. Військово-політична дестабілізація лише посилила прояви дестабілізуючих факторів у сфері ПЕК, обумовивши поглиблення кризових явищ в енергетичній та економічній сферах.

На рис. 3 схематично наведено модель, яка відображає місце операційної стратегії енергогенеруючого підприємства в «стратегічному 
наборі». Представлена модель певною мірою є спрощеною, оскільки не відображає усієї сукупності стратегій, зокрема функціональних, однак дозволяє відобразити основні пріоритети у різних сферах його діяльності за умови несприятливості зовнішнього середовища, тобто прояву системи чинників про які йшлося вище. 3 огляду на специфіку енергетичної сфери та незважаючи на особливості зовнішнього середовища, зорієнтованість конкурентної стратегії на лідирування за витратами є очевидною.

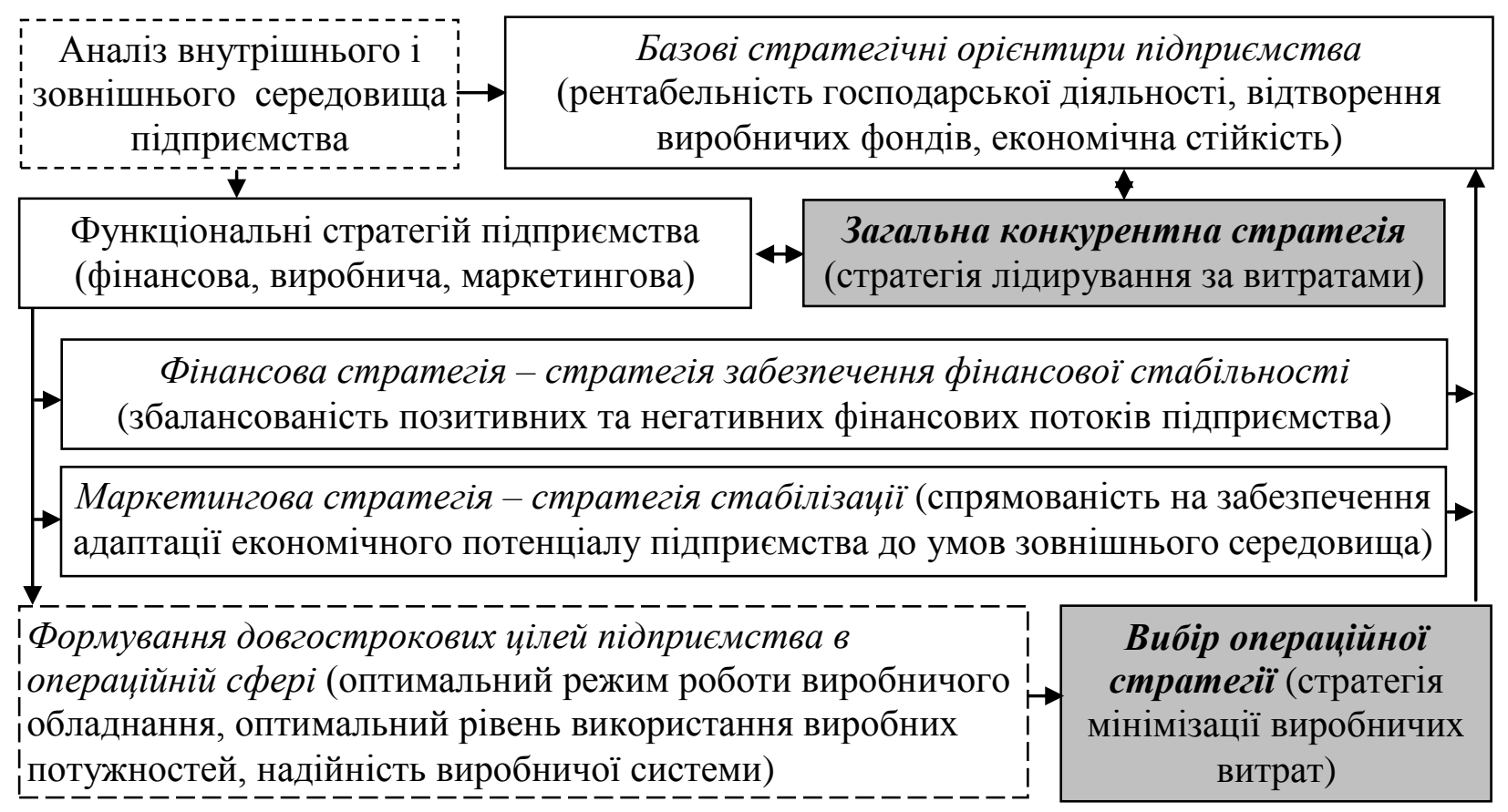

Рис. 3. Операційна стратегія енергогенеруючого підприємства в системі «стратегічного набору» (розроблено автором)

Перспективи ефективної реалізації даної стратегії в значній мірі визначаються саме тенденціями змін у зовнішньому середовищі. Підприємство може досягати збалансованості в режимі роботи обладнання, структурі енергетичного балансу, оптимізуючи тим самим систему витрат. Реалізація ж активної інвестиційної політики, впровадження технологічних та інших інновацій, відкриватиме додаткові, колосальні можливості у цьому напрямі, які в Україні надзвичайно мало використовуються, однак, які кардинально змінюватимуть ринки ПЕР у перспективі.

Стратегічноважливими завданнями розвитку енергогенеруючих підприємств залишаються модернізація виробничих фондів, впровадження нових технологій та створення стійких передумов надійного забезпечення паливом. Можна розглядати різні підходи до вирішення вказаних завдань. 3 точки зору макрорівня, пріоритетом $є$ завершення процесів формування повноцінних ринків ПЕР, покращення інвестиційного клімату 3 метою залучення стратегічних інвесторів. При цьому важливо досягати 
збалансованості в часі тих чи інших рішень. Адже трансформація ПЕК може відбуватися за умови прискорення темпів та підвищення якості економічного зростання. Що ж стосується мікро- та мезорівнів, то в умовах нестабільності, ресурсних обмежень, підприємства все ж змушені орієнтуватися на внутрішні можливості, які лежать в площині організаційно-економічних перетворень, спрямованих на розвиток їх адаптаційного потенціалу, формування якого певною мірою обмежуватиме стратегічну конкурентоспроможність, що являє собою свого роду «плату» за поточну нестабільність середовища.

Висновки. Таким чином, військово-політична та макроекономічна нестабільність, виносять на порядок денний цілий комплекс додаткових проблем пов'язаних з функціонуванням і розвитком енергетичного сектору. Їх розв'язання потребує концентрації зусиль як на рівні держави, так і на рівні господарюючих суб'єктів, які б дали змогу виробити узгоджену політику антикризової спрямованості. Колосальний потенціал нестабільності в економічній та енергетичній сферах обумовлює необхідність удосконалення систем управління енергетичними підприємствами, пошук управлінських механізмів, які б дозволяли ефективніше використовувати власні можливості. Зміни в системі операційного управління $є$ першочерговими, зусилля в процесі формування операційних стратегій мають спрямовуватися на зменшення витрат виробництва, що забезпечуватиме відповідні міжгалузеві ефекти в системі ПЕК та міжгалузевій системі економіки в цілому.

Наукова новизна дослідження полягає саме в систематизації основних чинників впливу на ефективність роботи енергогенеруючих підприємств 3 урахуванням технологічних особливостей їх роботи, міжфункціональних взаємозв'язків у галузевій структурі економіки, а також змін у зовнішньому середовищі, що дало змогу визначити вихідні засади удосконалення політки розвитку підприємств в частині формування операційних стратегій. Відповідно, перспективами подальших досліджень є розроблення механізму формування і реалізації зазначених стратегій, обгрунтування методологічних положень оцінювання їх ефективності.

\section{Література:}

1. Артеменко А.В., Моделирование эколого-экономического состояния территории / А.В. Артеменко, Н.В. Караева, Р.В. Корпан, Т.А. Коцко, И.В. Недин. / Под ред. И.В. Недина. - К.: Знания Украины, 2006. - 215 с.

2. Енергетичний сектор України. Дослідження на основі опитування учасників галузевого ринку / КПМГ в Україні. - 2013. - 23 с.

3. Інтегрований звіт ДТЕК за 2014 рік [Електронний ресурс]. - Режим доступу: http://www.dtek.com/library/file/annual-report2014-ua.pdf

4. Крістіне Розенбергер. Політика України в галузі енергетики / Фонд Конрада Аденауера. - 2012. - 28 c. 
5. Кузьмін О.С. Технологія вибору виробничих стратегій для машинобудівних підприємств / О.С. Кузьмін, Н.Я. Петришин / Вісн. Нац. ун-ту «Львів. Політехніка». - 2009. - №647. - С. 92-98.

6. Міністерство енергетики та вугільної промисловості України [Електронний peсурс]. - Режим доступу: http://mpe.kmu.gov.ua

7. Омельяненко Т.В. Проблемы и актуальные задачи развития теории производственной стратегии предприятия / Омельяненко Т.В. // Бізнесінформ. - 2013. №11. - С. 279-286.

8. Стерлигова А.Н. Операционный (производственный) менеджмент: Учеб. пособие. / А.Н. Стерлигова, А.В. Фель - М.: ИНФРА-М, 2009. - 187 с.

9. Суходоля О.М. Досвід реформування ринку електричної енергії в Україні / Суходоля О.М. // Стратегічні пріоритети. - №1 (30). - 2014 р. - С. 59-68.

10. Суходоля О.М. Енергетичний сектор України: перспектива реформування чи стагнації / О.М. Суходоля, А.Ю. Сменковський // Стратегічні пріоритети. - 2013. - № 2. C. 74-80.

11. Трут О.О. Операційний менеджмент: підручник / Трут О.О. - К.: Академвидав, 2013. - 348 с. (Серія «Альма-матер»). 